\title{
JUNK FOOD CONSUMPTION AND LIFESTYLE PATTERN AMONG UNDERNOURISHED CHILDREN IN JAMMU REGION
}

\author{
Pallavi Sharma1, Ashu Jamwal2, Sunil Dutt Sharma ${ }^{3}$, Rattan Singh Manhas ${ }^{4}$, Ghanshyam Saini ${ }^{5}$, Tarundeep Kour 6
}

${ }_{1}^{1}$ Registrar, Department of Paediatrics, GMC, Jammu, Jammu and Kashmir, India.

${ }^{2}$ Assocaite Professor, Department of Paediatrics, GMC, Jammu, Jammu and Kashmir, India.

${ }^{3}$ Associate Professor, Department of Paediatrics, GMC, Jammu, Jammu and Kashmir, India.

${ }^{4}$ Senior Consultant, Department of Paediatrics, J \& K Health Services, Jammu and Kashmir, India.

5 Professor, Department of Paediatrics, GMC, Jammu, Jammu and Kashmir, India.

${ }^{6}$ Dental Officer, DEIC, Department of Paediatrics, GMC, Jammu, Jammu and Kashmir, India.

\begin{abstract}
BACKGROUND
ABSTRACT

Changing lifestyles and easy availability both have led to increased consumption of junk food amongst all age groups. Such foods and beverages have low nutrient density, provide empty calories and have minimal amount of vitamins and minerals and their regular consumption can adversely affect our health. The association of junk food with obesity and cardiovascular risk factors has been well established, but less has been talked about its association with undernutrition.

Aims and Objectives- Current study was designed to assess the junk food consumption and lifestyle pattern among the underweight children.
\end{abstract}

\section{MATERIALS AND METHODS}

It is a prospective hospital-based study. Children aged 5-18 years, presenting to Paediatric OPD of a Medical College Hospital were screened for weight, height and BMI. Those with a BMI for age less than -2SD as per WHO BMI charts were included in the study. They were evaluated for dietary intake including junk food consumption, lifestyle pattern especially physical activity and screen time as per a predesigned proforma. The co-infections with which they presented were also evaluated. The height, weight and BMI of the parents were also recorded.

\section{RESULTS}

Out of the 203 study subjects, 58\% were from urban areas while $42 \%$ belonged to rural area. Majority of the children belonged to the middle class with $49.2 \%$ being from upper middle class and $39.2 \%$ from lower middle class. Fast food consumption was reported as more than 4 times per week by $48.80 \%, 2-4$ times/week by $43.20 \%$, at least once a week by $6.40 \% .62 .4 \%$ of children reported daily intake of sweetened beverages with $44.8 \%$ reporting intake of more than one per day. $27.6 \%$ of the children reported having sweetened beverages at least 2 to 4 times in a week. Skipping of breakfast was common among school going children and observed 2-4 times/week in $49.20 \%$, and $>4$ times/week by $6.0 \%$. About $57.60 \%$ children had purchased the school lunch 2-4 times/week from canteen, $13.60 \%>4$ /week and $10.80 \%$ at least once a week. In the study subjects, approximately $52 \%$ of children spent more than the recommended 2 hrs./day on screen, $32.4 \%$ spent $1-2 \mathrm{hrs}$. on screen. About $75 \%$ of the children met the WHO recommendations for physical activity (i.e. moderate to vigorous physical activity of at least 60 minutes/day).

\section{CONCLUSION}

Cheap processed junk food has adversely affected the health of ordinary people. Such foods contain empty calories and hardly any vitamins, minerals or proteins and may be an important contributor to under nutrition in both upper and lower middle class where non-nutritive processed food and sugary beverages have replaced the traditional nutritious food. Both urban and rural population have fallen prey to this malady.

\section{KEY WORDS}

Junk Food, Underweight, BMI.

HOW TO CITE THIS ARTICLE: Sharma P, Jamwal A, Sharma SD, et al. Junk food consumption and lifestyle pattern among undernourished children in Jammu region. J. Evolution Med. Dent. Sci. 2018;7(50):5373-5377, DOI: 10.14260/jemds/2018/1189

\section{BACKGROUND}

Junk foods are foods or beverages that have low nutrient density, provide calories primarily through fats or added sugars and have minimal amounts of vitamins and minerals.

'Financial or Other Competing Interest': None.

Submission 22-10-2018, Peer Review 23-11-2018,

Acceptance 29-11-2018, Published 10-12-2018.

Corresponding Author:

Dr. Ashu Jamwal,

Ram Niwas, 356-A,

Gandhinagar, Jammu-180004,

Jammu and Kashmir, India.

E-mail: ashu.sainik@gmail.com

DOI: $10.14260 /$ jemds $/ 2018 / 1189$
Foods such as chips, Kurkure, soft drinks, juices, ice creams, chocolates and snacks, classified as junk foods are quite popular among children. Such foods are deficient in iron, calcium and other trace elements, and their sodium content is very high. Some may contain chemicals, artificial colours, flavours and preservatives which are bad for health.(1) Regular and consistent consumption of such foods over a long period of time may be deleterious to health. Ready availability, low cost, commercial marketing strategies and peer pressure makes junk food popular with children. High fat and sugary taste being addictive attract the children to junk food over healthy food. $(2,3)$ 
Junk food has displaced more traditional diets and is now available in every neighbourhood. Biscuits, savoury snack packets and the likes, costing between five and ten rupees have replaced many meals for a large chunk of population across rural and urban India. These children also consumed less of fresh fruits and vegetables and had less of milk intake.(4)

An increased consumption of junk food has been reported among school aged children as these are widely available in and outside the schools, through variety of outlets. Sale of junk food in these outlets often competes with more nutritious school lunch schemes.(5)

India is fast becoming the diabetes and heart disease capital of the world. The association of junk food with obesity and cardiovascular risk factors is well established. At the same time India leads the world in terms of underweight people with almost half the nation's under-five being underweight.(6,7) Undernutrition is closely associated with communicable diseases like tuberculosis, malaria, pneumonia and diarrhoea. $(8,9)$

The present study attempts to identify four risk factors for eating behaviour i.e. fast food intake, sweetened beverages intake, skipping of breakfast and purchased lunch amongst the underweight children.

\section{MATERIALS AND METHODS}

All children 5-18 yrs. of age attending Paediatrics Department OPD of Shri Maharaja Gulab Singh Hospital (SMGS-H), Jammu every Thursday over a period of one month were screened, their height and weight recorded, and BMI calculated. The underweight children, i.e. those with BMI less than -2SD for age and sex as per WHO BMI charts were included in the study.(10) Their parents were explained the purpose of study and informed consent was taken. Sociodemographic details and history of present illness was taken, and a complete clinical examination was done focusing on the detection of comorbid conditions. Each patient's dietary quality, eating behaviour, screen time and physical activity were evaluated as per the designed Performa. The height and weight of parents were also recorded, and BMI was calculated.

The data was analysed using computer software Microsoft Excel and SPSS version 12.0 for windows.

\section{RESULTS}

- $\quad 800$ children aged 5-18 yrs., who visited the outpatient patient wing of the Department of Paediatrics a, SMGS hospital were screened by BMI. Of them 203 satisfied the inclusion criteria and were thus included in the study.

- $\quad$ The study group comprised of $112(55.17 \%)$ females and $91(44.82 \%)$ males. (Table-1)

- $59(29 \%)$ children were between 5- 9 yr of age, $55(27 \%)$ between $10-11$ yrs. and $89(43.8 \%)$ were more than 15 years of age. (Table -2)

- $\quad 88.4 \%$ of the children belonged to the middle class with $49.2 \%$ being from upper middle class and 39.2\% from lower middle class as per Modified Kuppuswamy Scale. (Table -3)

- $\quad 58 \%$ were from urban areas while $42 \%$ belong to rural area. (Table -4)

\begin{tabular}{|c|c|}
\hline Sex & Underweight \\
\hline Males & $91(44.82 \%)$ \\
\hline Females & $112(51.17 \%)$ \\
\hline $\begin{array}{c}\text { Table 1. Association between Sex Distribution and BMI of } \\
\text { Study Subjects (n=203) }\end{array}$ \\
\hline
\end{tabular}

\begin{tabular}{|c|c|}
\hline Age Distribution (Years) & Underweight BMI < -2 SD \\
\hline 5-9 yrs. & $59(29 \%)$ \\
\hline $10-14$ yrs. & $55(27 \%)$ \\
\hline >15 yrs. & $89(43.8 \%)$ \\
\hline Table 2. Association between Age Distribution and BMI of \\
Study Subjects (n=203) \\
\hline
\end{tabular}

\begin{tabular}{|c|c|c|}
\hline Family Status & Number of Patients & Percentage \\
\hline Upper class & 8 & $4.0 \%$ \\
\hline Upper middle & 100 & $49.20 \%$ \\
\hline Lower middle & 80 & $39.2 \%$ \\
\hline Lower class & 15 & $7.6 \%$ \\
\hline \multicolumn{3}{|c|}{$\begin{array}{l}\text { Table 3. Demographic Characteristics of Study Subjects } \\
(n=203)\end{array}$} \\
\hline Population & Number of Patients & Percentage \\
\hline Rural & 85 & $42 \%$ \\
\hline Urban & 118 & $58 \%$ \\
\hline \multicolumn{3}{|c|}{ Table 4} \\
\hline
\end{tabular}

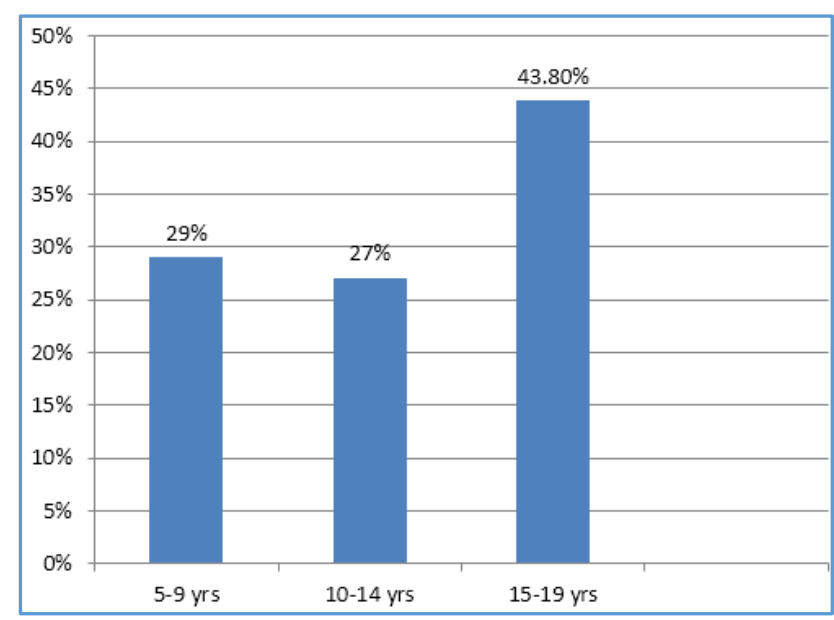

Figure 1

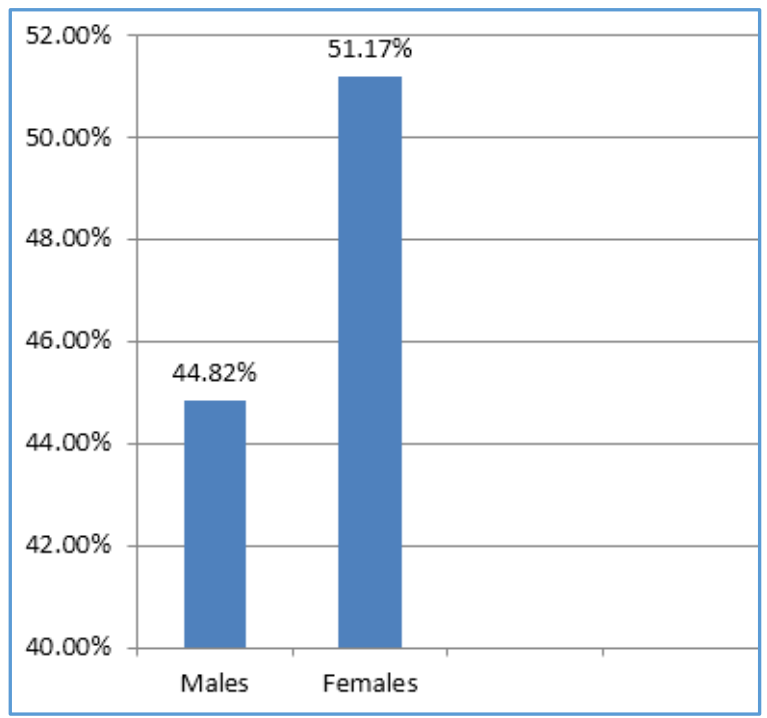

Figure 2 


\section{Feeding Characteristics of Study Subjects (Table -5)}

- $\quad 62.4 \%$ of children reported daily intake of sweetened beverages with $44.8 \%$ reporting intake of more than one per day. $27.6 \%$ of the children reported having sweetened beverages at least 2 to 4 times in a week.

- $\quad$ Skipping of breakfast was observed $>4$ times/week by $6.0 \%$., 2-4 times/week in $49.20 \%$, at least once a week by $22.70 \%$.

- $13.60 \%$ of children purchased school lunch from canteen more than 4 times/week, $57.60 \%$ children did it $2-4$ times/week and $10.80 \%$ at least once a week.

- $\quad$ Fast food consumption was more than 4 times per week by $48.80 \%, 2-4$ times/week by $43.20 \%$, at least once a week by $6.40 \%$ and $<1 /$ week by $1.60 \%$.

\begin{tabular}{|c|c|c|}
\hline Characteristics & No. of Patients & Percentage \\
\hline \multicolumn{3}{|c|}{ Sweetened Beverages } \\
\hline$<1$ week & 7 & $3.60 \%$ \\
\hline 1/week & 13 & $6.40 \%$ \\
\hline 2-4 times/ week & 56 & $27.60 \%$ \\
\hline $1 /$ day & 36 & $17.60 \%$ \\
\hline$>1 /$ day & 91 & $44.80 \%$ \\
\hline \multicolumn{3}{|c|}{ Breakfast Skipped } \\
\hline$<1 /$ week & 45 & $22.10 \%$ \\
\hline 1/week & 46 & $22.70 \%$ \\
\hline 2-4/week & 100 & $49.20 \%$ \\
\hline$>4 /$ week & 12 & $6.0 \%$ \\
\hline \multicolumn{3}{|c|}{ Purchased School Lunch } \\
\hline$<1$ week & 36 & $18 \%$ \\
\hline 1/week & 22 & $10.80 \%$ \\
\hline 2-4/week & 117 & $57.60 \%$ \\
\hline$>4 /$ week & 28 & $13.60 \%$ \\
\hline \multicolumn{3}{|c|}{ Fast Food Consumed } \\
\hline$<1 /$ week & 3 & $1.60 \%$ \\
\hline 1/week & 13 & $6.40 \%$ \\
\hline 2-4/week & 87 & $43.20 \%$ \\
\hline$>4 /$ week & 100 & $48.80 \%$ \\
\hline \multicolumn{3}{|c|}{ Table 5} \\
\hline
\end{tabular}

- In the study subjects approximately $52 \%$ of children spent more than the recommended $2 \mathrm{hrs}$./day on screen, $32.4 \%$ spent $1-2$ hrs. on screen.

- About $75 \%$ of the children met the WHO recommendations for physical activity (i.e. moderate to vigorous physical activity of at least 60 minutes/day).

- Children attended the hospital with acute illnesses, like gastroenteritis (30\%), worm infestation (21\%), anaemia (18\%), upper respiratory tract infection $(16 \%)$, urinary tract infection (12\%) and acute hepatitis (3\%).

\begin{tabular}{|c|c|c|}
\hline Characteristics & No. of Patients & Percentage \\
\hline TV - viewing/day & & \\
\hline$<1 \mathrm{hr}$ & 20 & $10 \%$ \\
\hline $1-2 \mathrm{hrs}$ & 66 & $32.4 \%$ \\
\hline $2-4 \mathrm{hrs}$ & 106 & $52 \%$ \\
\hline$>4 \mathrm{hrs}$ & 11 & $5.60 \%$ \\
\hline \multicolumn{2}{|c|}{ Table 6. Recreational Characteristics of Study Subjects } \\
\hline
\end{tabular}

Among the parents of study subjects $70.80 \%$ of mothers are obese, $17.20 \%$ are overweight, $7.60 \%$ are extreme obese and $4.40 \%$ are having normal BMI, whereas $75.20 \%$ of fathers are obese, $15.20 \%$ are overweight, $6.0 \%$ are extreme obese and $3.60 \%$ are normal. Hence degree of under nutrition did not correlate with parenteral nutrition (Table-7)

\begin{tabular}{|c|c|c|c|c|}
\hline BMI (kg/m2) & \multicolumn{2}{|c|}{ Mother } & \multicolumn{2}{c|}{ Father } \\
\hline & Frequency & $\mathbf{( \% )}$ & Frequency & $\mathbf{( \% )}$ \\
\hline Underweight (<18.5) & 0 & 0.00 & 0 & 0.00 \\
\hline Normal (18.5-24.9) & 10 & 4.90 & 7 & 3.40 \\
\hline $\begin{array}{c}\text { Overweight } \\
(25.0-29.0)\end{array}$ & 35 & 17.20 & 31 & 15.20 \\
\hline Obese (30.0-40.0) & 143 & 70.40 & 152 & 74.80 \\
\hline Extreme obese (>40.0) & 15 & 7.38 & 12 & 6.00 \\
\hline
\end{tabular}

Table 7. BMI of Parents of the Study Subjects ( $n=203)$

\section{DISCUSSION}

The prevalence of moderate and severe underweight is highest in South Asia; one in 5 girls aged 5-19 years and nearly one third of their male peers are underweight. Physical growth is a key indicator of child health.(11)

In the present study of 203 underweight children aged 518 years, 58\% were from urban and $42 \%$ from rural areas. Majority belonged to the middle class with $49.2 \%$ belonging to the upper middle class and $39.2 \%$ belonging to the lower middle class. Intake of fast food and sweetened beverages was common in all age groups. Skipping breakfast and purchasing school lunch was a commonly observed behaviour.

Gupta A et al in their study of children in the age groups 12-18 years from Govt Schools in the rural areas of Himachal Pradesh found high prevalence (36\%) of consumption of junk food. They found that most popular junk food item was chips (71\%) followed by chocolate $(14 \%)$ bakery products $(13 \%)$, soft drinks (7\%) and sugar sweetened beverages (5\%). They also observed that junk food was consumed mainly as snacks from shops outside the school. (12)

Kaur $\mathrm{M}$ et al in their study screened 2636 children aged between 4 and 15 years from rural schools and reported that fast food prevalence was high among all age groups and both the genders and nearly $60 \%$ of these consumed fast food on a daily basis. All the children had inclination for fast food and $25 \%$ skipped meals for fast food.(4)

Most of the western countries and few schools in India have banned the sale of junk food in school cafeteria. In United Kingdom and many European countries, all commercial activities in primary school are restricted as per the directive of Union Of European Beverages Association (UNESDA).(13) However, there is lack of stringent law and regulation pertaining to fast food sale in Indian schools.

In the present study these underweight children had reported to the paediatric outpatient department with various ailments like acute gastroenteritis (30\%), worm infestation $(21 \%)$, anaemia (18\%), upper respiratory tract infection $(16 \%)$, urinary tract infection $(12 \%)$, acute hepatitis (3\%). Childhood underweight is becoming increasingly important contributor to adolescent undernutrition and diseases, both deficiency as well as infections. Children who are undernourished are at increased risk of various infectious diseases due to weak immune system. The increased intake of fast food predisposes children to infections due to poor 
hygiene during preparation, storage and handling of junk food. $(9,14)$

Reicheit Ac \& Rank MM have also highlighted the negative impact of junk foods on cognition and behaviour during adolescence. They further proposed that poor dietary choices may derail the normal adolescent maturational process, which can predispose individuals to dysregulated eating and impulsive behaviour.(15)

Jalambo MO et al in their study of female adolescents aged 15-19 years reported significant association between iron deficiency anaemia and dietary habits like skipping breakfast and the amount of junk food consumed and cognitive impairment.(16)

Burrows et al in their review of literature reported that breakfast consumption and quality meal patterns had positive association with academic achievement whereas negative associations were reported with junk food.(17)

Children are on the receiving end of a barrage of fast food and sugary beverage advertising. Television advertisement plays an important role in promoting junk food by the use of animation and favourite cartoon characters. Exposure to marketing of energy dense, nutrient poor food and beverages has been shown to adversely affect children's eating habits.(18)

In the study subjects approximately $52 \%$ of children spent more than the recommended $2 \mathrm{hrs}$./day on screen, $32.4 \%$ spent $1-2 \mathrm{hrs}$. on screen.

Dixon HG et al, in a survey of 919 five and six grade students, reported that heavier commercial TV viewing was associated with more positive attitudes towards junk food and was independently associated with higher junk food consumption. They further concluded that changing the food advertising environment on children's TV to one where nutritious foods are promoted and junk foods are relatively unrepresented would help to normalise and reinforce healthy eating.(19)

Coon KA et al also reported that greater TV use has been associated with higher intakes of energy, fat, sweet and salty snacks, and carbonated beverages and lower intakes of fruits and vegetables, placing children at risk of poor nutritional status.(20)

Sadeghirad B et al in a systematic review and metaanalysis of randomised trials concluded that unhealthy food and beverage marketing increases dietary intake and preference for energy dense, low -nutrition food and beverage in children.(21)

An interesting observation in the present study was that in a number of households the parents are overweight and obese while the children are underweight. Rising family incomes and easy accessibility to junk food seem to have made middle class vulnerable to both forms of malnutrition i.e. obesity and underweight.

Black et al reported that maternal and child malnutrition in low income and middle income countries encompasses both undernutrition and a growing problem with overweight and obesity.(22) Van et al reported that fast food intake was common in young adults due to time limitations, convenience and taste. Television was reported to be the most effective medium influencing their food choices.(23)

Promotion of healthy eating habits and education of parents and children about junk food therefore need to be strengthened. Strict enforcement of the laws to regulate the marketing and advertising of junk food in and around school premises may also be helpful in reducing the consumption of junk food among school aged children.

\section{CONCLUSION}

Fast foods have become an important part of dietary menu for most children. There is a high prevalence of food consumption amongst the underweight children belonging to the upper- and middle-class families in both urban and rural areas. Individual counselling for children and their families on healthy eating habits, restricting junk food and replacing it with available, affordable traditional food is the need of the hour.

\section{REFERENCES}

[1] Kaushik JS, Narang $M$, Parakh A. Fast food consumption in children. Indian Pediatrics 2011;48(2):97-101.

[2] Rudert C. The effect of an unregulated fast food industry on nutrition in Asia. UNICEF EAPRO 26 August 2014.

[3] Jackson P, Romo MM, Castillo MA, et al. Junk food consumption and child nutrition. Nutritional anthropological analysis. Rev med Chil 2004;132(10):1235-42.

[4] Kaur M, Hegde AM. Are we aware of what we are, we are what we eat - an epidemiological survey. Int J Clin Pediatr Dent 2008;1(1):13-6.

[5] Missbach B, Pachschwoll C, Kuchling D, et al. School food environment: quality and advertisement frequency of child-oriented packaged products within walking distance of public schools. Preventive Medicine Reports 2017;6:307-13.

[6] Payab M, Kelishadi R, Qorbani M, et al. Association of junk food consumption with high blood pressure and obesity in Iranian children and adolescents: the CASPIAN - IV Study. J Pediatr (Rio J) 2015;91(2):196205.

[7] Wang Y, Chen HJ, Shaikh S, et al. Is obesity becoming a public health problem in India? Examine the shift from under - to over-nutrition problems over time. Obes Rev 2009;10(4):456-74.

[8] Padmapriyadarsini C, Shobana M, Lakshmi M, et al. Under-nutrition and tuberculosis in India: situation analysis and the way forward. Indian J Med Res 2016;144(1):11-20.

[9] Calder PC, Jackson AA. Under-nutrition, infection and immune function. Nutr Res Rev 2000;13(1):3-29.

[10] Cole TJ, Flegal KM, Jackson AA. Body mass index cut offs to define thinness in children and adolescents: international survey. BMJ 2007;335(7612):194.

[11] Global database on Child Growth and Malnutrition. UNICEF - WHO - The World Bank: Joint child malnutrition estimates - Levels and trends. 2018. www.who.org.

[12] Gupta A, Kapil U, Singh G. Consumption of junk foods by school - aged children in rural Himachal Pradesh, India. Indian J Public Health 2018;62(1):65-7.

[13] The UNESDA Commitments (http://www.unesdacommitments/no advertising-to-children-under-12/). 
[14] Jones TF, Angulo FJ. Eating in restaurants: a risk factor for foodborne disease? Clinical Infectious Diseases 2006;43(10):1324-8.

[15] Reichelt AC, Rank MM. The impact of junk foods on the adolescent brain. Birth Defects Res 2017;109(20):1649-58.

[16] Jalambo MO, Karim NA, Nasir IA, et al. Prevalence and risk factor analysis of iron deficiency and iron deficiency anaemia among female adolescents in the Gaza Strip, Palestine. Public Health Nutr 2018;21(15):2793-802

[17] Burrows T, Goldman S, Pursey K, et al. Is there an association between dietary intake and academic achievement: a systematic review? J Hum Nutr Diet 2017;30(2):117-40.

[18] Batada A, Seitz MD, Wootan MG, et al. Nine out 10 food advertisements shown during Saturday morning children's television programming are for foods high in fat, sodium or added sugars or low in nutrients. J Am Diet Assoc 2008;108(4):673-8.
[19] Dixon HG, Scully ML, Wakefield MA, et al. The effect of television advertisements for junk food versus nutritious food on children's food attitudes and preferences. Soc Sci Med 2007;65(7):1311-23.

[20] Coon KA, Tucker KL. Television and children's consumption patterns. A review of the literature. Minerva Pediatr 2002;54(5):423-36.

[21] Sadeghirad B, Duhaney T, Motaghipisheh S, et al. Influence of unhealthy food and beverage marketing on children's dietary intake and preference: a systematic review and meta-analysis of randomised trials. Obes Rev 2016;17(10):945-59.

[22] Black RE, Victoria CG, Walker SP, et al. Maternal and child under-nutrition and overweight in low-income and middle income countries. Lancet 2013;382(9890):427-51.

[23] Van MK, Steyn NP, Marais MI. Characteristics and factors influencing fast food intake of young adult consumers in Johannesburg, South Africa. S Afr J Clin Nutr 2010;23(3):124-30. 